\title{
PERFORMATIVITAS PERTUNJUKAN TARI RABBANI WAHID MEUGROUP DI SAMALANGA-ACEH
}

\author{
Virawati, Rustim, Roza Muliati \\ Minat Studi Pengkajian Seni Tari Program Pascasarjana \\ Institut Seni Indonesia Padangpanjang \\ Jl. Bahder Johan Padangpanjang 27128 Sumatera Barat \\ Email: virarancakbana @gmail.com
}

\begin{abstract}
Abstrak
Tari Rabbani Wahid merupakan salah satu kesenian masyarakat sufi yang berasal dari Desa Sangso, kecamatan Samalanga, Kabupaten Bireuen Aceh, tarian ini berangkat dari syair (zikir) sebagai pengiring tari. Penelitian ini membahas penerapan hubungan interteksi syair yang mempengaruhi gerak secara performatif, hubungan ini mampu membangun kehanyutan (flow) penari dalam pertunjukannya. Metode penelitian menggunakan pendekatan performance centered approach, yaitu pendekatan yang terpusat pada pergelaran. Hasil penelitian menunjukkan bahwa bagian terpenting dalam tari Rabbani Wahid adalah Meugrop yaitu melompat dan menghentakkan kaki dengan posisi berdiri disertai zikir. Tari Rabbani Wahid dipertunjukkan dengan kekuatan pengaruh zikir sebagai bagian pertunjukan alam bawah sadar. Kata kunci: Tari Rabbani Wahid, Performativitas, Sufi, flow, Aceh
\end{abstract}

Abstract

Rabbani Wahid dance is one of the arts of the Sufi community originating from Sangso Village, Samalanga District, Bireuen Aceh Regency; this dance departs from poetry (remembrance) as a dance accompaniment. This study discusses the application of the interaction of poetry that affects motion performatively; this relationship can build dancers' flow in their performances. The research method uses a performance-centered approach, which is a performance-centered approach. The results showed that the essential part of the Rabbani Wahid dance is Meugrop, which jumps and stomps in a standing position accompanied by remembrance. Rabbani Wahid dance is performed with memory as part of the subconscious show.

Keywords: Rabbani Wahid dance; Performativity; Sufi; flow; Aceh

\section{PENDAHULUAN}

Tari Rabbani Wahid tumbuh dan berkembang di desa Sangso Kecamatan Samalanga Kabupaten Bireuen-Aceh, tari ini bermula dari Meugrob, artinya melompat sambil berzikir dan membaca Allahu dan La Illaaha illallah, zikir yang dimaksud berbentuk teks syair dari Syekh Muhammad Saman. Rabbani Wahid artinya Allah Sang Rabbi yang satu dan berisikan puji-pujian kepada Allah dan Rasul. Pertunjukan tari Rabbani Wahid mencakup pelahiran gerak secara simbolik, maksud yang disampaikan dalam teks syair berisi tentang ajaran Islam.

Struktur gerak tari Rabbani Wahid terkesan dinamis dan variatif, pertunjukannya terdiri dari dua kelompok pelaku laki-laki, yaitu sepuluh orang penari dan tiga orang syekh. Kedua kelompok ini memiliki peran yang berbeda, namun tetap dalam satu kesatuan yang utuh. Syekh bertindak sebagai pemusik (menyanyikan syair-syair). Syair dinyanyikan secara berulang hal ini seperti sebuah penekanan komunikasi dalam teks syair, syair tersebut disertai dengan zikir atau salawat, yang di ikti oleh penari, pengulangan tersebut sebagai konsep performativitas dengan adanya hubungan secara horizontal sesama pelaku pertunjukan. Menurut Lyotard "performativitas merupakan bentuk 
informasi yang memiliki kekuatan, semakin banyak informasi yang seseorang miliki maka semakin banyak yang bisa diraih seseorang" (dalam Philip Auslander, 2006 : 133). Berdasarkan pemaparan tersebut, terjadi satu hubungan sebab dan akibat, kekuatan informasi terdapat pada hubungan teks syair yang bersifat naratif dengan gerak tari.

Tempo gerakan yang semakin lama semakin naik dari tempo lambat, sedang dan cepat, tempo ini berpengaruhi tenaga dalam gerak, semakin lama semakin kuat. Hal menarik dalam tari Rabbani Wahid adalah kekuatan syair sangat berpengaruh gerak demi gerak secara keseluruhan, syair di awali dengan salam dan di akhiri dengan kalimat zikir serta takbir diikuti oleh penari, seolah larut dan hanyut dalam gerak yang makin energik, hingga pada akhirnya satu persatu penari jatuh ke lantai. "kondisi flow ditandai dengan enam aspek yakni, pemusatan pikiran, tindakan, kehilangan ego, kontrol tindakan, umpan balik tindakan, tidak sadar diri" (Csikszentmihalyi, 1975:144). Untuk menuju titik kehanyutan tentunya ada faktor yang mempengaruhinya dan hal ini yang melatar belakangi perlunya pembahasan lebih lanjut.

Upaya untuk mengkaji dan memahami tari Rabbani Wahid, sebagai salah satu perwujudan dari interaksi pelaku pertunjukan, karena tari Rabbani Wahid yang ada di Desa Sangso, Kecamatan Samalanga, memiliki keunikan tersendiri sebagai satu kesenian bagian wujud dari kebudayan masyarakat Aceh, apa yang menjadi penyebab suasana larut tersebut muncul dan bagaimana efek yang terlihat secara keseluruhan pada pelaku tari Rabbani Wahid.

\section{STUDI LITERATUR}

Studi literatur dilakukan untuk mengetahui beberapa penelitian sebelumnya tentang Tari Rabbani Wahid dari berbagai sudut pandang, dan hal yang terkait kesamaan dengan objek. Hal ini diperlukan agar penelitian dapat diuji keaslian dan kelayakannya sebagai sumber ilmu pengetahuan, sehingga penelitian ini dapat dipertanggungjawabkan secara ilmiah. Penelitian yang berkaitan dengan tari Rabbani Wahid pernah dilakukan sebelumnya, berdasarkan penelusuran sumber kepustakaan. Adapun hasil penelitian tentang Tari Rabbani Wahid akan dijelaskan sebagai berikut:

"Rabbani Wahid Bentuk Seni Islam di Aceh" (Aslam Nur, 2012). Laporan Penelitian ini memuat tentang eksistensi tari Rabbani Wahid, tokoh dan bentuk pertunjukan tari. Pelaku dalam pertunjukan tari Rabbani Wahid ini melibatkan kaum pria yang dianggap sanggup melakukan gerakan-gerakan dalam waktu lama dan stamina prima. Terdapat kesamaan objek, namun penelitian yang dilakukan lebih terfokus pada proses pertunjukan dan berkaitan dengan sajian gerak distimulus oleh syair dalam sajian tarian tersebut.

"Makna Simbolik Gerak Tari Rabbani Wahid" (Abdul Manan, 2013). Sebuah jurnal tentang pembahasan makna gerak secara simbolik, tulisan ini mengurai tentang ragam gerak yang terdapat dalam tari Rabbani Wahid. Berbicara simbol dan makna gerak tari. Sementara itu dalam penelitian ini memuat tentang bagaimana proses terjadinya ketidak sadaran pelaku akan realita keseharian, bagaimana mereka masuk ke dalam aktivitas alam bawah sadar, sebagai bentuk tingkatan kehanyutan pelaku tari.

"Fenomena Pertunjukan Lukah Gilo 
Pada Masarakat Sabak Auh, Siak" (Desmiati, 2017). Sebuah jurnal tentang pertunjukan Lukah Gilo, dalam pembahasan berisi tentang bentuk pertunjukan pada upacara adat, berfungsi sebagai hiburan masyarakan dan melibatkan seorang pawang, manteramantera sebagai media hubungan pawang dengan Lukah Gilo, dalam tulisan tersebut ada kaitannya dengan Tari Rabbani Wahid yakni sama memiliki unsur trance, pelaku sama-sama melibatkan kaum laki-laki.

\section{METODE}

Penelitian ini merupakan penelitian kualitatif yang berbasis lapangan (field reserch). Pengumpulan data diperoleh secara langsung dari lokasi penelitian dalam bentuk pengamatan atau observasi, teknik ini dapat dilakukan melalui pengamatan pada objek yaitu, menyaksikan pertunjukan guna mendapatkan kebutuhan data primer dengan pendekatan performance centered approach, yaitu pendekatan yang terpusat pada pergelaran (Lono Simatupang, 2013). Selain itu untuk memenuhi data sekunder narasumber utama yakni pemain tari Rabbani Wahid, yaitu syekh dan penari berguna untuk menggali informasi yang tidak dapat dilihat dari data pertunjukan.

\section{PEMBAHASAN}

Pertunjukan merupakan tindakan pelaku yang ditontonkan, artinya apa yang ditampilkan dapat memberi efek pada penonton maupun pelaku pertujukan, terfokus pada pelaku tari Rabbani Wahid, performativitas menjadi dasar dalam pertunjukan pada gerak tari Rabbani Wahid, urutan syair potensinya adalah pada zikir, dan peranan syekh sebagai pengatur tontonan tersebut.
Performativitas berasal dari performatif, awalnya dikenalkan oleh Jhon L Austin Istilah .... "performatif", tentu saja, diturunkan dari "perform: ....: menunjukkan bahwa mengeluarkan ucapan adalah pelaksanaan suatu tindakan. (....). Berdasarkan ungkapan ini menggambarkan bagaimana sebuah tindakan terjadi seiring dengan tutur atau kata sebagai substansi awal, artinya kata dan tindakan yang sinergi dapat menjadi pemicu yang serius. Apabila dihubungkan dengan performativity berdasarkan pendapat Sechechner dengan istilah (is) tentang apa itu pertunjukan, tentunya berkaitan dengan masyarakat tertentu seperti kesenian, ritual, permainan, dan sehubungan dengan unsur-unsur strukturnya (Schechner, 2002:30).

Tari Rabbani Wahid dalam performativitas berkaitan dengan syair dan gerak, menjadi satu interaksi dalam satu kesatuan secara kontiniu dan tidak dapat diacak. Selain itu teks kalimat syair, tindakannya pada gerakan misalnya "salam" pada syair, terlihat adanya gerakan sesama penari saling bersalaman sesuai apa yang ada dalam teks. Performativitas itu terlihat pada gerakan yang saling merespon antar penari seolah terjalin dialog gerak, satu mengarah kekanan dan yang lainnya kearah yang berlawanan, sehingga menjadi satu bentuk saling berhubungan seperti sebuah hubungan tarik menarik atau seperti satu hubungan sebab-akibat.

Interaksi lainnya juga dapat dilihat dari masing-masing gerak penari, contohnya pada gerak tangan yang saling tumpang tindih, atau bergantian, serta berlawanan yaitu satu tangan gerak terbuka dan tangan yang lainnya gerak tertutup, sehingga terkesan lebih dinamis 
dan atraktif, dan respon penari, keseluruhan syair yang di ucapkan oleh syekh diikuti oleh penari, hal ini berlangsung lama dari awal sampai akhir pertunjukannya. Berkaitan dengan ungkapan Lyotard bahwa " informasi menjadi kekuatan dalam hal tindakan" (dalam Philip Auslander, 2006 : 133). Pengaruh syekh sebagai penentu utama berlangsungnya alur pertunjukan tari Rabbani Wahid, sehingga memberi pengaruh secara signifikan terhadap tindakan pelaku lain, tindakan diartikan dalam wujud gerak rampak yang terkesan seragam, saling menirukan dan saling bersentuhan satu sama lainnya sebagai hubungan interaksi, "interaksi mendukung komunikasi yang berupa gerak anggota tubuh, ekspresi wajah, intonasi bicara, kemudian dapat ditanggap secara simbolik" (Kusumastuti, 2006:2). Berdasarkan dengan ungkapan tersebut hal yang paling mencolok pada proses interaksi Tari Rabbani Wahid yakni syair membangun interaksi pada gerakan tari.

Pertunjukan tari Rabbani Wahid secara keseluruhan berkaitan dengan konteks performativitas, dikarenakan setiap ungkapan syair merupakan bentuk teks informasi yang mempengaruhi gerak penari mulai dari awal pertunjukan sampai akhir pertunjukan, kalimat dan kata-kata dalam syair adalah sebuah informasi yang berulang-ulang, selain itu hubungan secara horizontal dalam teks performativitas dapat dilihat pada pola lantai penari dari awal sampai setengah pertunjukan.

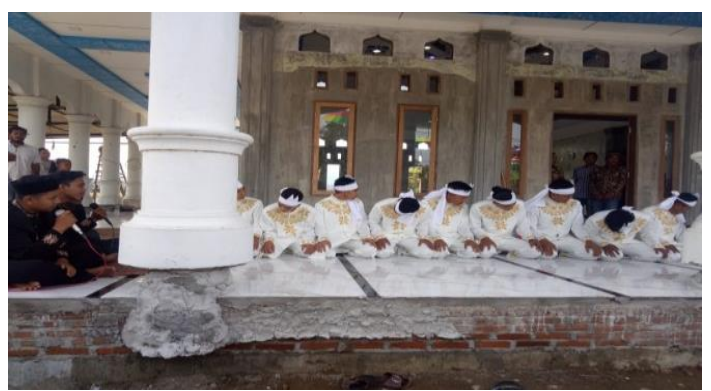

Gambar 1

Gerak dalam syair Hattahiyaton, sebagai salah satu pola terjadinya interaksi syekh dan penari (dokumentasi: Virawati, Sanggar Seulang, Samalanga, 15 November 2020)

Tari Rabbani Wahid pada awalnya memiliki fungsi sebagai sarana penyampaian ajaran-ajaran agama Islam, seperti halnya tari Saman, Seudati dan tari Aceh lainnya, penyampaian ajaran pendidikan Islam, atau sebagai media dakwah yang diungkapkan melalui syairsyair berisi nasehat dan peringatan atas suatu tindakan yang bertentangan dengan ajaran Islam. "Seni pertunjukan mempunyai tiga fungsi primer yaitu: 1) sebagai sarana ritual, 2) sebagai sarana hiburan, 3) sebagai presentasi estetis" (Soedarsono, 1998:57). Rabbani Wahid termasuk pada salah satu fungsi tersebut yakni sarana ritual dan hiburan.

Selain fungsi internal, tari Rabbani Wahid sebagai hiburan dalam memperingati hari-hari besar Islam, seperti menyambut satu Syawal sebelum masyarakat melaksanakan sholat id (hari raya Idul Fitri) yang dilakukan saat malam hari Idul Fitri sampai menjelang subuh, pelaku mengisi waktu sambil berzikir dan bersalawat. Pada kesempatan lain, tari Rabbani Wahid juga sebagai media hiburan dalam kegiatan sosial masyarakat, seperti satu kegiatan sunat Rasul, dan acara perkawinan dan peumulia jamee (penyambutan tamu). Fungsi internal Tari Rabbani Wahid sebagai media berkumpulnya para pelaku pada saat 
tertentu, misalnya setelah melakukan kegiatan kegamaan, mereka mengisi waktu sambil melantunkan syair. Pelaku menjalin silaturrahmi antar pemain dan bercengkrama satu sama lain, pada kesempatan tersebut pemain merespon isian nasehat, yang disampaikan oleh syekh seperti dalam salah satu teks syair yang kesembilan "Hasan Tsumma husen" yang berisikan tentang kehidupan duniawi manusia, dan tindakan keji yang tidak terpuji.

Tari Rabbani Wahid dalam pertujukannya termasuk tari berkelompok, yang melibatkan sejumlah orang sebagai pelaku pertunjukan, seperti melibatkan syekh dan penari, terkait struktur gerak tari Rabbani Wahid meliputi aspek-aspek secara koreografi, yakni penentuan jumlah penari dan pola formasi. "penetapan jumlah penari menjadi pertimbangan dalam koreografi, jumlah ini dapat melibatkan kecil atau besar dalam kelompok, baik gasal maupun genap" (Sumandiyo Hadi, 2007:45). Bedasarkan penjelasan di atas, hal ini perlu diulas karena gerak sebagai media terpenting dalam tari. Gerak tari Rabbani Wahid melibatkan jumlah penari genap, keseluruhan wujud dalam gerak akan menimbulkan maksud dan kesan yang berbeda, berdasarkan elemen gerak dalam koreografi. Bentuk gerakan tari Rabbani Wahid yakni gerak unison (serentak) dan gerak canon (bergantian), saling merespon serta menyilang, pada bagian ini terbentuk hubungan secara sinkronik dengan syair sebagai faktor yang mempengaruhi gerak dan menjadi hubungan secara paralel dengan syair. Posisi penari dibagi menjadi dua bagian yaitu, bagian pertama posisi penari duduk bersimpuh membentuk pola garis horizontal (bersyaf), dominan gerak tangan membuka dan menutup, bagian kedua posisi penari berdiri membentuk pola lingkaran, yang didominsi oleh gerakan kaki. "saling ketergantungan antara gerak, waktu dan ruang merupakan hal yang pokok dalam sifat tari” (Y.S Hadi, 2003:62). Tiga aspek tersebut menjadi penting dalam struktur gerak tari Rabbani Wahid, sehingga muncul dinamik gerak dalam pertunjukan tari berkelompok, berkaitan dengan syair dan gerak dipengaruhi oleh tempo syair.

Tari Rabbani Wahid melibatkan sepuluh orang kaum laki-laki (ureung agam) berusia remaja sampai dewasa, dibagi menjadi dua kelompok yang berbeda posisi, melibatkan tiga orang syekh dengan posisi duduk berdampingan, mereka bertugas menyampaikan syair demi syair, apeet syekh bertindak sebagai pengulangan irama syair seperti satu penekanan teks syair. Kemudian diposisi penari melibatkan sepuluh orang dibagi menjadi dua kelompok dalam struktur gerak secara visual, yakni masing-masing kelompok berjumlah lima orang dengan gerak yang berlawanan, (desain gerak atas dan bawah, serta desain gerak depan dan belakang), alasan yang sangat relevan mengapa penari tari Rabbani Wahid melibatkan kaum laki-laki, menurut Hasballah, "laki-laki yang mampu melakukan gerak tari dalam waktu lama, fisik yang kuat dan stamina prima" (wawancara: Hasballah, 13 November 2020). Atas dasar inilah pelaku tari Rabbani Wahid sampai saat ini tidak melibatkan kaum perempuan seperti halnya yang terjadi pada tari lain.

a). Ruang Gerak Tari Rabbani Wahid

Ruang gerak tari Rabbani Wahid dapat diidentifikasi dominan dengan ruang gerak pribadi, karena gerak yang 
dilakukan oleh penari kebanyakan gerak ditempat, dan hanya sebatas jangkauan tubuh mampu mencapainya, pada bagian tertentu, gerak dilakukan dengan ruang besar tetap dalam formasi penari bersyaf.

b). Tenaga Dalam Gerak Tari Rabbani Wahid

Gerak sangat berkaitan dengan tenaga sebagai sumber energi, tenaga yang intens akan memunculkan aksen gerak dan lebih menarik, tenaga yang lebih kuat terkesan bersemangat, begitu juga sebaliknya jika energi yang dikeluarkan cenderung lebih sedikit akan memberikan kesan yang berbeda pula, hal yang paling menonjol dalam tari Rabbani Wahid ini adalah, pengaruh energi yang dimunculkan oleh penari, semakin lama mereka semakin berenergi dan itu muncul dengan sendirinya secara mengalir tanpa dibuat-buat, gerak dilakukan secara totalitas. "Mereka bergerak sangat kuat, sehinngga lantai yang diinjak bisa retak" (wawancara: Yuswar, 14 November 2020).

\section{c). Pempo Gerak Tari Rabbani Wahid}

Tempo gerak dalam ilmu koreorafi yakni cepat dan lambat, cepat lambatnya satu gerak diukur dengan tempo yang ada pada musik, tempo gerak tari Rabbani Wahid mengalami perubahan mulai dari awal gerak sampai ahkir, semakin lama semakin meningkat atau semakin lama semakin cepat, hal ini tentunya berkaitan dengan energi dan stamina penari melakukan gerak tersebut.

\section{d). Pola Lantai Tari Rabbani Wahid}

Posisi dalam sebuah tari merupakan hal yang penting sebagai salah satu elemen tari, karena posisi penari akan memberikan kesan tertentu. Tari Rabbani Wahid memiliki dua bentuk pola lantai yakni, pertama formasi horizontal (syaf) penari dengan posisi duduk dan kedua penari membentuk posisi lingkaran, pada posisi syaf gerak lebih terlihat dinamis dengan kesan kebersamaan, sedangkan pada posisi penari melingkar gerak terkesan lebih kuat dan terfokus, perbedaan pola lantai ini lazim disebut dengan rateb duek untuk posisi duduk, dan rateb doeng untuk posisi berdiri. "Posisi duduk syaf sebagai simbol berjamaah dalam aktivitas ibadah, sedangkan posisi melingkar sebagai arti rotasi kehidupan yang ada di dunia yang dilalui oleh manusia, mulai dari manusia tidak ada sampai pada manusia dikumpulkan pada suatu masa oleh Tuhan (wawancara: Yunus, 13 November 2020).

e). Level gerak Tari Rabbani Wahid

Tari Rabbani Wahid memiliki level gerak dalam pertunjukannya, yakni level gerak rendah pada rateb duek (ratib duduk), rendah diartikan dengan adanya gerak badan yang menunduk ke lantai, kemudian level gerak tinggi pada rateb doeng (ratib berdiri), bagian ini terlihat gerakan melompat dalam formasi penari melingkar.

\section{f). Iringan Tari Rabbani Wahid}

Substansi pertunjukan tari Rabbani Wahid adalah zikir yang berperan sebagai iringan tari dalam bentuk teks syair berupa pantun dibagian meugrop yakni, narasi tentang keistimewaan syekh Muhammad Saman, berikut teks syair tari Rabbani Wahid

Bagian pembuka posisi duduk

\section{Saleum (Salam)}

Pola lantai tari bersyaf dengan level rendah, adanya gerak berjabat tangan dan pada bagian ini ditutup dengan gerak tepuk, gerak rampak simultan saling 
berbalasan antar penari, dalam gerakan ini memiliki simbol saling menghormati, salam sebagai doa keselamatan bagi saudara seiman.

Asalamualaikum warah mathullah (Asalamualaikum warah mathullah)

Jaroe dua blah ateuh jeumala

(dua belah tangan diatas kepala)

Karena saleum Nabi Kheeu

(karena salam sunnah dari Nabi)

Jaroe tamuma tanda mulia

(tangan bertemu tanda mulia)

Pada bagian ini interaksi terlihat jelas digambarkan dalam syair, bagaimana seseorang menjalin hubungan dan merespon satu sama lainnya.

2. Dengon Bismillah (Dengan
Bismillah)

Gerak diawali dengan tangan di dada dan menepuk lantai, ada dua motif gerak yang berbeda, yakni gerak rampak dan selang-seling, syair mengandung makna puji-pujian pada Allah yang menciptakan aturan-aturan dalam kehidupan manusia sebagai ciptaanNYA.

Dengoen bismillah rahmanirrahim

(dengan bismillah rahmanirrahim)

Alhamdulillah rabbal'alamin

(Alhamdulillah rabbal'alamin)

Permulaan hakiki

(permulaan hakiki)

Nyan yang aseuli ya allah

(itu yang asli ya Allah)

Dua perkara

(dua perkara)

Berdasarkan teks syair mengisyaratkan satu tindakan positif, sehingganya apa yang dilakukan sesuai dengan yang semestinya.

3. Salatullah

Awal gerak seperti orang yang sedang berzikir, tangan penari di atas paha masing-masing, kemudian gerakan dilanjkutkan dengan menepuk lantai secara bergantian ke atas dan ke bawah, bagian ini berisikan pesan nasehat tentang sholat, manusia menuju kehidupan sesudah kematian, karena hanya dengan sholat sebagai media manusia berkomunikasi dengan Sang penciptaNYA. Salatullah salamullah

(Salatullah salamullah)

'Alayasin habibillah

('Alayasin habibillah)

Hai yo hai taulan dum beumeuuah

(wahai semua sahabat)

Dho takubah ateuh mushala

(letakkan dahi di atas mushola)

Sembahyang limongmeubek tatinggai

(sholat lima waktu janganlah tinggal)

Meu nyang keuh pangkai meu nyang that raya

(itulah modal yang paling utama)

Syair mengingatkan tentang kewajiban, kepatuhan setiap manusia pada Tuhannya, seperti yang sudah dilakukan oleh pemimpin sebelumnya.

Bagian Tengah.

4. Allah Rabbani

Seluruh penari melakukan gerak serentak dan variasi gerak dengan tangan menyilang didada serta menepuk paha, makna yang ada pada bagian ini yakni keimanan dan keyakinan pada Allah serta pada malaikat-malaikan sebagai bukti keEsaanNya, meyakini tiada tuhan selain Allah zat maha tunggal.
Allah rabbani Allah rabbani Ka neu berkati malaikat arbani Malaikat muqarabin
(Allah rabbani Allah rabbani) (yang telah memberkati Malaikat arbani) (Malaikat muqarabin) 
Malaikat muekahne 10 droe

Ka beu tatusoe mandum nyan nama

5. Hattahiyaton

Bagian urutan ini adanya pengulangan motif gerak dalam syair dengon bismillah, makna yang ada pada

Hatta hiyatun nama di kaye

Timoh peureude dalam syurga

Mubarakatun nama dicicem

Dicoeng kaye nyan tuhan karoe nya

6. Sultan

Bagian ini terdapat dua motif gerak yang berbeda, yaitu canon dan simultan, (malaikat ada 10 orang)

(harus kita tahu semua nama)

bagian ini yaitu keindahan, perbandingan dunia dan syurga, sebuah keyakinan bahwa syurga hanya diperuntukkan bagi orang yang beriman dan keta'atan.

(Hatta hiyatun nama pohon)

(tumbuh akar dalam syurga)

(Mubarakatu nama burung)

(diatas pohon allah yang ciptaan)

makna yang disampaikan adalah Allah sang penguasa segalanya.

Sultan-sultan maujudon alhamdulillah (Sultan-sultan maujudon alhamdulillah)

Maujum wahidon khairuhul fani (Maujum wahidon khairuhul fani)

Raja-raja yang maujul kasidroe allah (raja-raja yang kekal Allah yang Esa)

Yang laen ubah dumlawan fhana

(yang lain dari padanya berubah akan sirna)

7. Din awai din

Urutan gerak dalam syair dominan silang-seling, makna pada bagian ini mengenalkan agama Allah.

dengan gerak tepuk tangan, serentak dan Din awai din awailuddin muarifatullah Sidroe tuhan beuta nyakin Laen mungken mandum muhaddas Awai agama tuhan beutaturi

Bek han meuri ka tapeucaya Yang peuna dilee bandum geutany Yang keuh poe droe tuhan yang Esa

(Din awai din awailuddin muarifatullah)

(hanya tuhan yang kita yakini)

(yang lain tentunya sementara) (pertama agama tuhan tentu dikenal)

(jangan sembarang beriman)

(yang telah menciptakan kita semua)

(itulah milik Allah yang Esa)

Bagian Akhir posisi berdiri

8. Hasan Summa Husen

yakni rendah dan tinggi, makna yang disampaikan kepuasan dan nafsu

Bagian ini terdapat empat motif gerak yang berbeda, dilakukan secara penggambaran syair tentang kisah hasan dan husen. serentak, terdapat dua level yang berbeda

Hasan summa husen jamaloi Husen jamaloi

Siploh uroe buleun muharam Ke sudahan husen jamaloi Hasan husen cucoe di nabi Aneuk bak siti fatimah zuhra Syahit di husen teuma dalam pramg Syahid di hasan inoeng bri tuba (hasan dengan husen jamolai)

(husen jamolai)

(sepuluh hari bulan muharram)

(meninggal hasan jamolai)

(hasan husen cucunya Nabi)

(anak dari Fatimah Zuhra)

(Sahid husen ketika dalam perang)

(sahid hasan diberi racun istrinya) 
9. Syaidillah

Bagian ini disebut meugrop (hentakan kaki), dengan pola lantai melingkar dan level gerak tinggi dengan

Syaidillah-syaidillah $2 x$

Saidillah Muhammad saman

Syadillah-syaidillah

Ya... alem Muhammad saman

Yadillah-syadillah $2 x$

Ya wali yullah Muhammad saman

Syadillah-syadillah $2 x$

10. Allahu

Bagian paling akhir gerak penari

Beu ingat-ingat Allahu bak tadrop gajah Bauna ta keu bah taloe yang raya

Beu ingat-ingat allahu taubat bak allah Tataubat beu sah allahu bek sia-sia

Berdasarkan urutan syair dalam tari Rabbani Wahid didominasi teks zikir yang disampaikan dalam dialek daerah, bagian akhir disebut dengan Meugrop, pada awalnya meugrop dilakukan di tempat ibadah seperti mushola, dan balai pengajian dengan kontruksi bangunan kayu. "Zikir sering dilakukan oleh kelompok sufi sebagai media untuk mencapai ketenangan diri, hiburan individu, mengosongkan fikiran tentang kehidupan duniawi, dan berkonsentrasi pada Allah" (Isma'il R. Al-Faruqi, 2003: 329). Urutan syair tari Rabbani Wahid ini memiliki empat ragam syair dalam kategori asli, yakni: a). Dengan Bismillah, b). Allahu, c). Hasan Summa Husen, d) Din awai din, selebihnya adalah syair tambahan yang menjadi variasi, syair tambahan tersebut disesuaikan dengan. gerakan serentak, makna yang ada tentang utusan Allah memiliki tingkat keimanan yang sangat tinggi.

(Syaidillah-syaidillah 2x)

(Saidillah Muhammad saman)

(2x Syadillah-syaidillah 2x)

(Ya... alem Muhammad saman)

(Yadillah-syadillah 2x)

(Ya wali yullah Muhammad saman)

(Syadillah-syadillah 2x)

saling berpegangan dalam posisi melingkar, identik dengan kalimat tasbih, makna tentang kebesaran Allah.

(Ingat-ingat Allah ketika tangkap gajah) (ada kita simpan tali yang besar)

(Ingat-ingat allah taubat pada allah)

(taubat harus sah Allah tak sia-sia)

\section{Proses Flow Pada Tari Rabbani Wahid}

Efek yang muncul dalam sebuah pertujukan tentunya dapat dirasakan oleh pelaku atau orang yang menonton pertunjukan tersebut, hal ini dapat diperhatikan dari gerak secara visual, ada aspek-aspek penting di dalamnya. "Enam sifat khas mimik ditandai dari sisi interior lain, 1). Tindakan dan kesadaran, keduanya merupakan satu kesatuan pengalaman, 2). Perhatian terpusat pada batas rangsangan, 3). Kehilangan jati diri (Ego), 4). Aktor menemukan dirinya dalam kontrol tindakan dan lingkungannya, 5). Kehanyutan sebagai umpan balik tindakan dengan arah yang jelas dan bukan tindakan yang ambigu. 6). Tidak sadar diri” (Csikszentmihalyi, 1975:144).

Mengacu pada poin di atas dapat diidentifikasi dalam tari Rabbani Wahid, yakni: 
1). Tindakan dan kesaradan dapat gerak gelombang dalam syair diidentifikasi saat penari melakukan "Hattahiyaton", gerak memiliki tingkatan gerak rampak dan gerak yang saling kesulitan yang memerlukan pengontrolan merespon, penari melakukan gerakan dan kehati-hatian penari, terdapat level dengan tempo yang mengalami perubahan secara kontiniu, menyadari berada dalam satu tempo gerakan antar sesama penari, setiap gerakan yang muncul distimulus oleh teks syair, tindakan dan kesadaran terdapat pada gerak "Salam", salam yang dimaksud bukan hanya sekedar kalimat tetapi salam sebagai suatu tindakan, hal serupa juga terdapat dalam syair "Allah Rabbani”.

2). Perhatian terpusat pada batas rangsangan, hal ini dapat terlihat pada visualisasi gerak tari Rabbani Wahid disetiap gerakan menggunakan tingkatan tempo gerak yang teridiri dari tiga level, yakni tempo lambat, sedang dan cepat, gerakan menyesuaikan dengan tempo yang ada pada syair yang diucapkan syekh, keterkaitan tempo ini menjadi rangsangan gerak penari secara keseluruhan mulai dari gerak "salam awal" sampai dengan gerak "Allahu" bagian akhir pertunjukan.

3). Kehilangan jati diri (Ego), aspek ini dapat dilihat pada gerakan "Lailahailallah" ditandai dengan seluruh penari saling merangkul satu sama lain, pada bagian ini penari membutuhkan enargi diluar dirinya sendiri, penari melepaskan diri dari kesehariannya dan berada pada keadaan trans kedalam alam fikiran mereka masing-masing, dengan tingkatan keyakinan sebagai satu hubungan vertikal, terlihat dengan ucapan "Lailahailallah" yang mulai tidak serentak.

4). Aktor menemukan dirinya dalam kontrol tindakan dan lingkungannya. yang berbeda dalam waktu yang sama, kontroling gerak ini sangat penting sebagai satu tindakan, sebab akan menimbulkan cidera pada penari lain, jika hal tersebut tidak disadari oleh penari, selain itu pada pola lantai lingkaran juga termasuk sebuah pengontrolan tindakan, jika salah satu penari tidak mampu melakukan kontroling tindakan maka bentuk pola lingkaran tidak akan tercipta dengan sempurna.

5). Kehanyutan sebagai umpan balik tindakan, poin ini dapat dilihat dari bentuk gerak disetiap ragam gerak, baik dari segi arah gerak, arah hadap penari yang saling berlawanan, garis gerak dan ruang gerak baik sesama penari maupun gerak masingmasing anggota tubuh penari.

6). Tidak sadar diri (Flow)

Alam bawah sadar pelaku berkaitan dengan intensitas energi penari, selain itu zikir yang berulang secara terus menerus menjadi salah satu faktor munculnya kehanyutan, dan pemusatan pikiran berkaitan dengan tingkat keyakinan hingga menjadi titik tolak kehanyutan dalam pertunjukan tari Rabbani Wahid hingga penari jatuh ke lantai, penari tidak merasakan kesakitan saat jatuh kelantai, meski ada di antara menimpa tubuh penari lain, penggambaran suasana terakhir penari seakan berada dalam jiwa yang tenang. Hal ini tidak dapat dilakukan oleh penari jika mereka tidak merasakan hiburan atau kenikmatan tersendiri dalam dirinya, pada dasarnya tarian ini memang benar-benar pingsan, meski saat ini terkesan dibuat-buat akan tetapi secara simbolik hal itu masih dapat dilihat.

Kontrol tindakan terlihat pada 


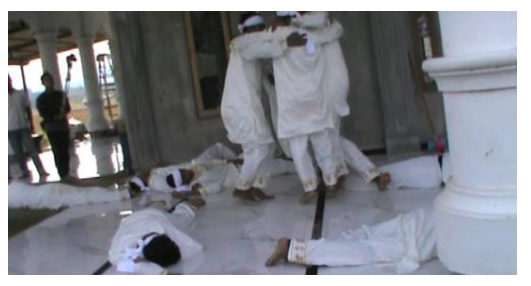

Gambar 2

Gerak terakhir kondisi penari tidak sadar/ flow, penari jatuh kelantai

(dokumentasi: Virawati, Sanggar Seulang, Samalanga, 15 November 2020)

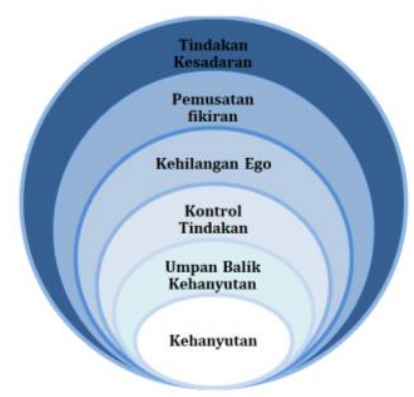

Gambar 3 .

Pola Tahapan Flow

Gambar : Virawati, 2020

\section{KESIMPULAN}

Meugroup dalam tari Rabbani Wahid merupakan hal yang terpenting, meugroup itu sendiri artinya bergerak dengan hentakan kaki yang kuat sambil mengucapkan zikir. Pertunjukan tari Rabbani Wahid melibatkan para pemain laki-laki dalam dua bentuk kelompok yakni kelompok syekh dan kelompok penari yang menjadi satu kesatuan yang saling terkait satu sama lain, keterkaitan tersebut dapat diidentifikasi baik melalui hubungan syair dengan gerak dan juga melalui bentuk gerak antara penari satu dengan penari lainnya, serta bentuk gerak penari yang diungkapkan melalui anggota tubuh sebagai media pengungkapan. Gerak saling berlawanan seperti sebuah hubungan tarik menarik. Hal serupa dapat dilihat dari ruang gerak yang timbul dalam tari ini. Interaksi yang dimaksudkan merupakan satu bantuk performativitas dengan adanya hubungan horizontal antar pelaku tari Rabbani Wahid yang ada dalam pertunjukan tari. Syair sangat memberikan kontribusi yang kuat dalam pelahiran dan perubahan gerak. Dalam hal ini terjadi bentuk interaksi berbalasan antara syekh dan penari, karena setiap pengulangan syair diikuti oleh penari sambil melakukan gerak mulai dari gerakan awal sampai akhir. Hubungan teks syair sebagai ungkapan kata yang diikuti oleh setiap gerak yang ada, terlihat jelas dalam gerak salam yang mengandung arti hubungan antar manusia.

Performativitas ini menjembatani kemunculan kehanyutan penari, di mana syair menstimulus pikiran pemain, peran syekh penentu dinamik pertujukan dan berpotensi sebagai penentu tempo gerak sebagai salah satu unsur gerak, tercapainya titik kehanyutan yang dirasakan oleh penari mengalami pembentukan pemusatan pikiran dan kosentrasi penari, sehingga energi penari semakin lamasemakin meningkat. Tempo gerak berubah semakin lama semakin cepat, pemusatan pikiran yang dialami oleh penari terlihat dengan adanya syair dan gerak yang 
berulang-ulang, sehingga pada titik akhir Nur Aslam. (2012) "Rabbani Wahid penari satu persatu jatuh kelantai, perubahan kesadaran menjadi tidak sadar atau flow.

Bentuk Seni Isam Di Aceh". Banda Aceh: BPNB. Aceh.

Schechner, Richad. (2002). "Performance Studies : An Introduction", London

\section{DAFTAR PUSTAKA}

Al-Faruqi R Isma'il. (2003). "Atlas Budaya Islam". Mizan: Bandung. Auslander Philip. (2008). "Theory For Performanc Studies". Routledge: London And New York.

Csikszentmihalyi. (2014). Flow. "Flow and The Foudations of Positive Psychology". New York: Harpercollins.

Desmiati. (2017). "Fenomena Pertunjukan Lukah Gilo Pada Masarakat Sabak Auh, Siak”. Jurnal ISI Padangpanjang.

Hadi Sumandiyo. (2007). "Kajian tari Teks dan Konteks". Yogyakarta: Pustaka Book Publisher.

Kusumastuti, Eny. (2006). "Laesan Sebuah Fenomena Kesenian Pesisir: Kajian Interaksi Simbolik Antara Pmain Dan Penonton". Harmonia Jurnal Pengetahuan dan Pendidikan Seni, Vol. VII. Nomor 3. Semarang. UNS

Manan Abdul. (2013). "Makna Simbolik Gerak Tari Rabbani Wahid". Jurnal Ilmiah Peuradeun. Vol. 2, No1. SCAD Independent. and New York: Routledge

Soedarsono. (1998). "Seni Pertunjukan Di Era Globalisasi”. Yogyakarta: Gadjah Mada University Press. 